\title{
Sir Tobie Matthew's Flaming Hart: translating Teresa for the English Catholic exiles*
}

The Libro de la vida was first published in Salamanca in 1588, six years after the death of its author, inspirational mystic and foundress of the Discalced Carmelite Order, Teresa of Ávila (1515-1582). ${ }^{1}$ The 1588 Vida was edited by Fray Luis de León who, in the dedicatory epistle he addressed to Prioress Ana de Jesús and the descalzas of the Madrid convent, claimed that familiarity with Teresa's texts led him to feel that he knew the author herself. Fray Luis admits that he never met Teresa while she lived, yet he states plainly that 'agora que vive en el cielo la conozco y veo casi siempre en dos imágenes vivas que nos dejó de sí, que son sus hijas y sus libros'. ${ }^{2}$ This idea, that Teresa's texts offer the reader intimate knowledge of their author, has been repeated in modern times, by Elizabeth Stopp, for instance. Comparing Teresa of Ávila and Francis de Sales, Stopp observes that '[i]n their own age and ever after, both have enjoyed immense popularity as real living people, as friends, in their writings; every reader has the impression we know them personally, as indeed we do' ${ }^{3}$

Such a response to the Vida is understandable since the work is an autobiography of sorts: it is natural for the casual reader to identify the autobiography's narrative voice with the authentic, unmediated voice of the woman who wrote it. This approach to the reading of autobiography would appear to be justifiable if Lejeune is right that the 'identity between the

\footnotetext{
* I am grateful to the British Academy and the Leverhulme Trust for the grant that enabled me to undertake in the UK, Belgium and Spain research essential to my work on The Flaming Hart.

${ }^{1}$ The Libro de la vida was printed by Guillermo Foquel, alongside two more of Teresa's major works, the Camino de perfección and the Castillo interior. The volume bore the generic title Los libros de la madre Teresa de Jesús, fundadora de los monasterios de monjas y frailes carmelitas descalzos de la primera regla.

${ }^{2}$ Fray Luis de León, Obras completas castellanas, 2 vols (Madrid, 1991), I, p. 904; 'now that she abides in heaven I know her and see her almost always in two living images of herself that she left us, which are her daughters and her books'. Translations are my own unless otherwise stated.

${ }^{3}$ Elizabeth Stopp, 'Spanish Links: St Francis de Sales and St Teresa of Ávila', in A Man to Heal Differences: Essays and Talks on St Francis de Sales (Philadelphia, 1997), p. 172, quoted by Joseph F. Chorpenning, 'St. Joseph in the Spirituality of Teresa of Ávila and of Francis de Sales: Convergences and Divergences', in The Heirs of St. Teresa of Ávila, edited by Christopher Wilson (Washington DC, 2006), pp. 123-40 (p. 126).
} 
author, the narrator, and the protagonist' is an absolute condition of the genre. It stands to reason too that readers of autobiography - at least those unfamiliar with, or unpersuaded by, poststructuralist analyses - read with the specific intention of gaining knowledge not just of the vicissitudes of the life narrated, but of the narrator's character too; indeed, for many that will be the principal focus of interest. This readerly endeavour, to encounter the author through the autobiographical text, finds support, again, in modern theoretical writing: for Anderson '[a]utobiography resituates the writer in his work, thus mitigating the dangers of the anonymity and the alienation of modern authorship: "The presence of his signature, the narrative unfolding of his history, inscribes the text as belonging to [the author], who becomes 'knowable' to his readers and inseparable from this text.", 4 And when the author knowable through the text is a saint - Teresa was canonized in 1622 - the common desire to come to know the author through her writing can, among pious readers, be augmented into a resolve to emulate her.

The importance of the author-subject's narrative voice as an indicator of character makes the translation of autobiographical writing an especially sensitive undertaking, then. My essay will examine the approach to this task taken in an influential early translation into English of Teresa’s Vida, Sir Tobie Matthew’s Flaming Hart of 1642, a book ‘found in many libraries’ - 'très répandu parmi les catholiques anglaises' ('very widely circulated among English Catholic women') in particular - and one whose impact has been felt inside the cloister and outside, in the seventeenth century and more recently. ${ }^{5}$ Scholars have observed how it was via translations such as Matthew's that 'Tridentine influences crossed national European

\footnotetext{
${ }^{4}$ Linda Anderson, Autobiography, The New Critical Idiom (London, 2001), pp. 2 and 8. Anderson quotes Philippe Lejeune, 'The Autobiographical Contract', in French Literary Theory Today, edited by Tzvetan Todorov (Cambridge, 1982), p. 193, and Mary Jean Corbett, Representing Femininity (Oxford, 1992), p. 40. Corbett is discussing the case of Wordsworth.

${ }^{5}$ Caroline Bowden, 'Building libraries in exile: The English convents and their book collections in the seventeenth century', in British Catholic History, 32 (2014-15), pp. 343-82 (p. 370). Maurice Sabbe, 'La Typographie Anversoise au XVII' et au XVIII Siècle', in Histoire du Livre et de l'Imprimerie en Belgique des Origines à nos Jours, vol. 4 (Brussels, 1925-26), p. 69, quoted in J. P. Vander Motten and Katrien Daemen-De Gelder, 'A Cloistered Entrepôt: Sir Tobie Matthew and the English Carmel in Antwerp', in English Studies, 92 (2011), pp. 548-61 (p. 552).
} 
boundaries, in this instance Spanish culture spreading outwards to English convents' and, from there, to the wider Anglophone world. ${ }^{6}$ Translations constitute an important and still understudied aspect of the reception history of pan-European figures such as Teresa. Before turning to my analysis of The Flaming Hart translation, though, I shall make some brief comments concerning its (and Teresa's) influence on the seventeenth-century English.

\section{[1 line \#]}

Within the cloister Teresa's writing appears to have been of considerable importance. ${ }^{7}$ Bowden has established 'the presence of multiple copies of Teresian texts' in the exiled English convents of the early modern period. ${ }^{8}$ The Antwerp English Carmel, for instance, owned five seventeenth-century editions of Teresa's spiritual autobiography: three English translations, one French and one edition in the original Spanish. ${ }^{9}$ Since some of the exiled nuns 'struggled' with foreign languages, the procurement of appropriate reading material in English was a priority and the exiled convents played their part in the genesis of translations into English of

\footnotetext{
${ }^{6}$ Caroline Bowden, James E. Kelly and Michael C. Questier, 'Introduction', in The English Convents in Exile, 1600-1800: Communities, Culture and Identity, edited by Caroline Bowden and James E. Kelly (Farnham, 2013), pp. 1-15 (p. 10). On the importance of translations of Spanish devotional works see also Carlos Eire, 'Early modern Catholic piety in translation', in Early Modern Cultural Translation, edited by Peter Burke and R. Pochia Hsia (Cambridge, 2007), pp. 83-100.

${ }^{7}$ Geoffrey Scott identifies Teresa as 'the European nun who principally provided by her spiritual teaching an inspiration and role model for seventeenth-century English nuns' ('Cloistered Images: Representations of English Nuns, 1600-1800', in The English Convents in Exile, pp. 191-208 (p. 201)).

${ }^{8}$ Bowden, Kelly and Questier, op. cit., p. 10. In the wake of the dissolution of the monasteries in England and the enactment of anti-Catholic penal laws, convents for English nuns were displaced to, or set up on, the continent, especially northern France and the Spanish Netherlands.

${ }^{9}$ The Antwerp English Carmel, founded in 1619, owned copies of all three English translations of the Vida published during the seventeenth century: (i) The Lyf of the Mother Teresa of Iesus (Antwerp, 1611) usually attributed to Michael Walpole; (ii) Tobie Matthew's Flaming Hart; and (iii) The Life of the Holy Mother S. Teresa ([London], 1671), translated by Abraham Woodhead. In addition, the convent owned a French translation, La vie de la séraphique mère Sainte Thérèse de Jésus (Lyons, 1670), as well as a Spanish edition of the Vida contained within a collected Obras de la gloriosa madre santa Teresa de Iesus (Madrid, 1678). These volumes are part of the archives of the Antwerp and Lierre English Carmels now held at Douai Abbey, Berkshire. I am grateful to Abbot Geoffrey Scott and the Benedictine community at Douai for their kind hospitality and for permission to examine these archives.
} 
continental spiritual and devotional treatises, including Teresa's Vida. ${ }^{10}$ Nicky Hallett has shown that Teresa's Life was regularly mentioned as a factor crucial in inspiring religious vocations in the life writings of the exiled English nuns, the content and style of which clearly bear the imprint of Teresa's own autobiography. ${ }^{11}$ It was felt too that Teresa's inheritance strengthened the political clout of her successors. There was a strong sense that considerable authority lay in the written records of her life and of her Discalced Order, the nuns, interestingly, expressly aware of the priority of the Spanish originals. Discussing the Teresian constitutions in the early eighteenth century, Sister Mary Joseph of St Teresa notes frostily, for example, how the friars 'falsified in ye French translation as it appears by ye Spanish original'. ${ }^{12}$ The trust placed in the translator of the saint's works, and the expectation that the englished Teresian corpus would reflect faithfully the saint's original Spanish, were considerable, then. The task of translating the Vida fell to Sir Tobie Matthew (1577-1655).

A well-known - some would say notorious - Catholic convert and court intriguer, Matthew had established a reputation before 1642 as a translator of religious texts out of Latin and out of Italian and Spanish, vernaculars he acquired during extended sojourns on the continent. Following the making of fanciful allegations that he was involved in a plot to kill the king, Matthew, long considered a dangerous ‘court papist’ by the Anglican establishment and the Puritans, fled to the continent in April 1641 to escape arrest and the febrile atmosphere of an England on the brink of Civil War. He joined the sizeable community of English Catholic exiles present in the Spanish Netherlands and seems to have developed a close relationship with the Antwerp Carmel in particular. ${ }^{13}$ It was by the request of 'the Reverend Mother

\footnotetext{
${ }^{10}$ Nicky Hallett, Lives of Spirit: English Carmelite Self-Writing of the Early Modern Period (Aldershot, 2007), p. 5. Teresa of Ávila was not the only Spanish writer with a living presence in these communities. The Antwerp English Carmel owned copies of treatises by Juan de Ávila, Juan de Castaniza, Jerónimo Gracián, Luis de Granada, Francisco de Losa, Juan Eusebio Nieremberg and Alonso Rodríguez, the majority in English translation, several by Matthew.

${ }^{11}$ Hallett 2007, pp. 19, 67, 79, 173 \& 212.

12 Quoted in Hallett 2013, p. 112.

13 There exist a number of biographies of our translator. Most easily accessible is A. J. Loomie, 'Matthew, Sir Toby (1577-1655)' in the Oxford Dictionary of National Biography (Oxford, 2004). The fullest is John P. Feil,
} 
Superiour of the English Teresian-Carmelites, at Antwerpe, and the rest of that holie Assemblie' that Sir Tobie was 'moved ... to Translate, out of Spanish, into English, the Life of the Admirable, and Blessed Woeman, S. Teresa, their holie Mother, and mine’ (f. *5). ${ }^{14}$

The nature and extent of the influence of Teresa's works on the laity of early modern England remains to be established, but the case of Richard Crashaw offers one noteworthy example of the literary impact of her autobiography and of The Flaming Hart translation in particular. Crashaw (1613-1649) is one of the best-known English poets to have converted to Catholicism in the seventeenth century and his later work bears the clear imprint of Teresa's writings. Referring to the third piece of the trilogy that this metaphysical poet dedicated to the saint, published in the collection Carmen Deo Nostro, Te Decet Hymnus, Sacred Poems (Paris, 1652), R. V. Young insists that Teresa's 'direct influence [on Crashaw] is undeniable’ and verifies that he 'was acquainted with [Matthew's] translation', holding that this 'is sufficiently demonstrated by his use of the same title, “The Flaming Hart,” for one of his Teresa poems'. Indeed, Young holds that Teresa was 'undoubtedly the single most important influence on [Crashaw's] later poems', observing the 'simple paradoxical tone, compounded of equal measures of popular piety and mystical profundity, of light-heartedness with spiritual earnestness’ that he believes Crashaw learned from Teresa’s writings. Crashaw’s ‘An Apologie for the fore-going Hymn', addressed to the saint, refers expressly to '[t]hine own dear books' and to 'reading thee', this last expression illustrating again the pervasive conflation in the reader's mind of autobiographical author and narrator, even when dealing with a translated text. $^{15}$

'Sir Tobie Matthew and his Collection of Letters', unpublished PhD dissertation, University of Chicago, August 1962. I hope to address in some detail the matter of Matthew's links with the Antwerp English Carmel in a future publication.

${ }^{14}$ Quotations are from Tobie Matthew (translator), The Flaming Hart or the Life of the Glorious S. Teresa (Antwerp: Jan van Meurs, 1642). I have spelled out contractions and regularized the use of $u / v$ and $i / j$ in quotations. The full text is available through Early English Books Online. I have also examined the physical copy held at the library of Christ Church, Oxford (shelfmark WS.8.10).

${ }^{15}$ R. V. Young, Richard Crashaw and the Spanish Golden Age (New Haven, CT / London, 1982), pp. 19, 51 and 130. As well as demonstrating Crashaw's debt to Teresa, Young's study opens a rare window onto the more 
In recent times too a number of scholars working within a range of disciplines have had recourse to Matthew's seventeenth-century translation, preferring it to the twentieth-century English translations that have for most purposes superseded it. ${ }^{16}$ Generally - when a reason is given - the choice results from a sense that The Flaming Hart is preferable because of its relative chronological proximity to the early modern subjects these scholars have as their principal focuses. In her study of The Senses in Religious Communities, 1600-1800 (2013), for example, Nicky Hallett chooses Matthew's translation because it was 'known to the Antwerp and Lierre communities' about which she writes. ${ }^{17}$ Peter Tyler makes reference to several English translations of the Vida in his Teresa of Avila: Doctor of the Soul (2013), but holds that, of all the saint's English translators Tobie Matthew 'was probably closest to Teresa's daughters and her late sixteenth century Spanish usage'. ${ }^{18}$ And in his essay 'Partakers of Pain: Religious Meanings of Pain in Early Modern England’ (2009), Jan Frans van Dijkhuizen uses the 1642 translation as his primary source for his discussion of the place of pain and suffering in Teresa's mystical discourse, not unreasonably quoting from the translation as though the words were Teresa's. ${ }^{19}$ Despite the sustained interest in The Flaming Hart, however, Woods is right that 'Matthew's translation of Teresa's autobiography remains under-studied' ${ }^{20}$ It is frequently mentioned, but little tends to be said about it. The analysis the follows is intended to cast light on the curious idiosyncrasy of Matthew's English Teresa, a woman in several important respects rather different from the protagonist of the Spanish Vida.

\footnotetext{
general influence of Spanish baroque poetry on this English metaphysical poet. Like Matthew, Crashaw spent time on the continent living within the Catholic exile community, locus of an important but largely overlooked interface, I think, between Spanish and English culture.

${ }^{16}$ Namely, E. Allison Peers (translator), The Complete Works of St Teresa of Jesus first published by Sheed \& Ward in 1946, and Kieran Kavanaugh and Otilio Rodríguez (translators), The Collected Works of St. Teresa of Avila, first published by the Institute of Carmelite Studies (Washington, DC) in 1976.

${ }^{17}$ At p. 6, n. 13.

${ }^{18}$ London, p. 82.

${ }^{19}$ In The Sense of Suffering: Constructions of Physical Pain in Early Modern Culture, edited by Jan Frans van Dijkhuizen and Karl A. E. Enenkel (Leiden / Boston, MA), pp. 189-220.

${ }^{20}$ Chance Woods, 'Reading the Catholic Mystical Corpus in Seventeenth-Century England', unpublished Master of Arts dissertation, Vanderbilt University, August 2012, p. 41, n. 26.
} 


\section{[1 line \#]}

The style of Teresa of Ávila's Libro de la vida is extremely distinctive and creates a strong impression of the author-subject's character. Chicharro describes the text as having a 'personalidad inconfundible’ ('unmistakable personality’). Blanca de los Ríos comments that '[1]a prosa de Santa Teresa es inseparable de su espíritu [y] conserva la impronta de su alma’ ('Saint Teresa's prose is inseparable from her spirit and bears the imprint of her soul'). And for E. Allison Peers ‘every page bears the indelible impress of her forceful and vivid personality’. 'For Spaniards', he claims, 'there is no writer whose personality communicates itself with greater immediacy'. ${ }^{21}$

Teresa's style has been the subject of scholarly debate since the mid-twentieth century, but its peculiarities long before struck many of the saint's readers, including Sir Tobie Matthew who, like the translators who have followed him, seems to crave sympathy and indulgence from his audience for the ordeal he has suffered in attempting to grapple with this challenging text. ${ }^{22} \mathrm{He}$ (a little unjustly) dismisses the efforts of Teresa's first English translator (William Malone, responsible for the 1611 Lyf of the Mother Teresa), observing uncharitably that 'he seemed to have lost a little of the puritie of his owne English Toung, and ... not to have acquired enough of the Spanish' (f. ${ }^{*} 6^{\mathrm{r}}$ ), but then seeks to pre-empt criticism of his response to the difficulties he too evidently encountered. These were caused, Matthew explains:

\footnotetext{
${ }^{21}$ Dámaso Chicharro (editor), Santa Teresa de Jesús, Libro de la vida (Madrid, 1997), p. 62. Blanca de los Ríos, 'Influjo de Santa Teresa en nuestra literatura mística y ascética', in Monte Carmelo, 1914 (quoted in Chicharro (editor), p. 64). Peers (translator), The Complete Works of St Teresa of Jesus (London, 1978), p. xiv.

${ }^{22}$ I do not propose here to engage in the long-running academic dispute that pits those who believe that Teresa's style is sincere and unaffected (for some, a product of her gender) against those who consider it the result of artifice, a deliberate rhetoric that exploits tropes (for some, again, typically associated with what has been described as her female style) designed to achieve specific goals. For an overview of this debate, see Alison Weber, Teresa of Avila and the Rhetoric of Femininity (Princeton, NJ, 1990), pp. 5-11, and Elena Carrera, Teresa of Avila's Autobiography: Authority, Power and the Self in Mid-Sixteenth-Century Spain (Oxford, 2005), pp. 58.
} 
Partly, through the high, and abstracted Nature of the verie Contents of the Booke; Partly, through the great length of the Periods; Partly through the multitude, sometimes, of Parenthesis, even in the same sentence; Partly, through her forbearing to use those Particles, in the beginning of the said Sentences; as namelie, For, But, Yet, Therefore, and the like; without which, it is not always so easie to discerne, whether the Discourse be either continued, or interrupted or ended. (f. * $\left.6^{r-v}\right)^{23}$

In fact, Tobie Matthew meets these challenges rather successfully in his translation, which is certainly more easily digestible than the Spanish original, difficult for the reasons given. The rarefied subject matter, frequent ellipses, anacoluthon, digression and asyndeton are just some of the characteristics of Teresa's Vida, however. Her extremely expressive style is also characterized by self-deprecation, diffidence, imprecision, colloquialism, affectivity (communicated in particular by diminutives and superlatives) and the general avoidance of learned and technical lexis. ${ }^{24}$ Cumulatively, these features create an unpretentious, sympathetic and charismatic autobiographical persona that most readers of the Spanish find immensely attractive. As I shall now begin to demonstrate, Matthew's approach to the translation of these characteristic features of Teresa's prose style results in the creation of quite a distinct persona for the English Teresa who speaks through the pages of The Flaming Hart.

Self-deprecation is a salient feature of Teresa's Vida, seen by many critics as an attempt at captatio benevolentiae prompted by the author's awareness that some of her original readers were likely to view her supernatural experiences and her desire to teach her mystical prayer techniques to others with suspicion if not outright hostility. Matthew evidently finds Teresa’s

\footnotetext{
${ }^{23}$ In his 'Carta dedicatoria' Fray Luis too notes some of these difficulties, though he simultaneously heaps praise on Teresa’s prose style (op. cit., p. 909).

${ }^{24}$ I shall not discuss Teresa's phonetic mis-spellings, her metatheses or her semi-phonetic transliterations of Latin here. These - a feature of Teresa's manuscript original, which many modern editors choose to reproduce - are not found in the sixteenth- or seventeenth-century Spanish printed editions that most readers in the period, including Sir Tobie, would have known.
} 
self-deprecation problematic. He goes as far as to issue an express 'word of Advertisement to the Reader' (f. $* 4^{v}$ ) on the matter and goes on to note, in his preface, that as regards questions of her own virtue and vice 'she would never trust her owne eyes ... but she resolved to worke with Perspective Glasses’ (f. ${ }^{* * r}$ ), playing down her virtues and exaggerating her vices. While there is plenty of self-deprecation left in The Flaming Hart - Matthew does not take the same gross liberties as certain other early modern translators - he does frequently choose to tone the self-deprecation down. On countless occasions in the Vida, Teresa describes herself as ruin, a wicked woman, undeserving of the great favours God has chosen to bestow upon her through unitive prayer, visions and raptures. On the whole, in the Spanish text, Teresa asserts the fact of her sinfulness plainly and directly. Not so the Teresa who speaks to the reader in Matthew's translation. In chapter 19, for instance, following enumeration of the manifold mercies God shows to unworthy souls, Teresa characteristically exclaims '[q]ue no sè, como no se me parte el coraçon, quando esto escrivo porque soy ruin' (p. 166; 19.5). ${ }^{25}$ Tobie Matthew prefers to present the saint's wretchedness not categorically, as in the Spanish, but merely as her subjective impression, translating 'I cannot understand how my heart comes not, even to splitt, when I write this much; because I find my self so very wicked?' (p. 237). Similarly, during the difficult negotiations with which Teresa had to struggle to found San José in Ávila, the first Discalced Carmel, with the primitive rule and in the Spartan manner she believed divinely ordained, she faced opposition and, on occasion, reprimand from her superiors. When she tells of a punishment she received Teresa is typically gracious in her observation that it was

\footnotetext{
${ }^{25}$ Quotations from Teresa's Vida are taken from Las obras de la Santa Madre Teresa de Jesús published in Antwerp in 1630 at the Officina Plantiniana (Biblioteca Nacional shelfmark R/24082 V.1). From this point on, where there is emphasis in quotations taken from this text (and from The Flaming Hart) it is mine unless I state otherwise. I use emphasis to draw attention to the discrepancies between the two texts. I consider the 1630 edition of the Vida to be the most likely source text for Matthew's translation. An explanation of the basis for this opinion is beyond the scope of the present essay. In any case, the variants between the multiple Spanish editions published before 1643 are not significant for the purposes of this study.
} 
relatively light; it was 'una grande reprehension, aunque no con tanto rigor, como merecia el delito’ (p. 381; 36.12), not so fierce as the offence deserved. For Matthew, evidently it seemed impossible that the saint's actions as foundress could merit censure: the punishment administered, he translates, was great, 'though not yet, with so much rigour, as the fault might seem to deserve' (p. 555). A further instance of this translation bias occurs when Teresa presents neutrally the petty jealousies that her intimacy with Doña Luisa de la Cerda provoked among this great lady's servants. Teresa assumes that '[d]evian por ventura pensar que pretendia algun interesse' (p. 352; 34.5). Matthew chooses to clarify as absurd the idea that Teresa might have thought to derive some worldly benefit from the friendship: 'perhaps', he writes, 'they were so ill advised, as to imagine, that I had some thought of interest, by what I did' (p. 512), forgetting that it is Teresa's thoughts he is expected to present to his reader and not his own, tinged as his reading is with surprise at the failure of envious servants to appreciate her goodness. Finally, by way of example of Matthew's toning down of Teresa's selfdeprecation, let us consider another case of an objective observation on the saint's part being converted into a subjective assessment (the implication is, an erroneous one). On several occasions in the Vida Teresa calls on her principal addressee, 'Vuesa Merced' (one of her confessors, García de Toledo), to tear up her account if it constitutes mere prattle or if it offends against the Catholic truth. Part way through chapter 10 Teresa insists that she is writing merely under obedience: 'yo digo lo que ha passado por mi, como me lo mandan; y si no fuere bien, romperàlo à quien lo embio’ (p. 166; 10.7). This time it seems that Sir Tobie finds the notion that the saint's words might offend to be implausible, but he understands that Teresa's readers (not she herself) might fall into error. Teresa calls on García de Toledo to destroy her text if it is no good. Matthew translates: 'I relate, what hath occurred to me; as they, who have power over me, command, and if he, to whom I send it, doe not like it, he may teare it' (p. 114). To 
repeat, in Spanish Teresa anticipates the fault being hers. In English she merely conceives that what she writes might not be to her reader's taste.

Tobie Matthew’s translation of the Vida goes further in altering the self-presentation of the original author. Not only does he often - though not systematically - tone down Teresa's self-deprecatory remarks, he sometimes also positively enhances the sense given of her exemplarity, even suggesting her saintliness, casting into stark relief the very different circumstances in which the two editions of the text under consideration were composed, a difference to which I shall return later. If, in the Vida, Teresa dwells on her own shortcomings, she is quick, usually, to see extraordinary goodness in others, even those who cause her suffering. She is perplexed as to why these pious Christian souls are not granted the same spiritual favours as she is and why sometimes God appears to abandon them. She wonders '[¿்]porque, Señor, dexais unas personas muy santas, que siempre os han servido[?]' (p. 167; 19.6). Matthew's translation highlights his reluctance to accept Teresa's self-exclusion from the class of 'personas muy santas', of very holy people. His small addition to The Flaming Hart blurs the distinction made clearly in the Vida between the mujercilla ruin (the author) and las personas muy santas: the English Teresa asks 'why, O Lord, dost thou passe over those other holie people, who have alwaies served, and suffered for thee[?]' (p. 237). ${ }^{26}$ The exact same addition is made in chapter 31, in which Teresa expresses her pleasure that a priest with whom she was acquainted, fallen into mortal sin, should have mended his ways when God granted him mercy by forgiving those sins 'at the instance of those many other holie persons, to whome the busines had been recommended' (p. 451). The Spanish refers only to 'las muchas personas muy santas' (p. 310; 31.7). Obviously, Teresa does not include herself among these santos: that would have been the height of immodesty. And yet that is exactly what Sir Tobie Matthew has

\footnotetext{
${ }^{26}$ The other addition to this translation - the giving of a pair of participles ('served, and suffered') for the single one in the Spanish ('servido') - is one of Sir Tobie Matthew's most characteristic tics. Bush lists 'the habit of rendering single words by two or three' as one of the 'common sins of the Elizabethan translator' (English Literature in the Earlier Seventeenth Century, 1600-1660 (Oxford, 1962), p. 59).
} 
his English Teresa do, resulting in the communication to the Anglophone reader of explicitly mixed messages. ${ }^{27}$

One wonders how the Inquisitors into whose hands a manuscript copy of Teresa's Vida fell would have reacted if she had really spoken as Matthew has her speak in The Flaming Hart of the direction given to her by the learned Dominican Fray Pedro Ibáñez, to whom she had entrusted the decision on whether to press ahead with the San José foundation. ${ }^{28}$ In the Spanish, Teresa plainly suggests her subordination to this esteemed letrado when she recalls that Ibáñez 'nos respondiò, nos diessemos priessa à concluirlo, y dixo la manera y traça que se avia de tener' (p. 335; 32.17). His words are presented as orders by the Spanish Teresa. Not so the English Teresa: the Dominican's answer 'was, that we should make what hast we could, to conclude it; And he also let us know his opinion of the way, and manner, which we were best to hold in it' (p. 487). Clearly this is not a faithful translation. I think readers familiar with Teresa's texts will understand, though, why Matthew chose to render the phrase as he did. As she - knowingly or unwittingly - reveals in the Vida and her Fundaciones, Teresa had a habit of consulting a range of letrados till she found one who sanctioned the course of action on which she was set. In the Spanish version we catch glimpses of this single-minded wilfulness (always applied altruistically) by reading between the lines of Teresa's narrative. But Tobie Matthew seems here to be attempting to resolve some of these pervasive textual tensions by altering Teresa's words. In doing so he risks editing out subtle, often amusing sightings of the saint's mischievousness: of course, one suspects that Ibáñez’s ruling would have been treated as merely one opinion had it gone against Teresa. The Spanish Teresa's voice, however, would not openly have referred to it as such, either for fear that she would be accused of disobedience or because the thought processes glimpsed through her narration of her dealings leading to her

\footnotetext{
${ }^{27}$ I refer to these as 'explicitly' mixed messages to distinguish them from the subtler, implicit mixed messages that can be detected in the Vida by any careful reader. For example, Teresa tends to confess her sinfulness in very non-specific terms and then, subsequently, to explain why in fact she was not really to blame.

${ }^{28}$ For details of the circumstances that led to inquisitorial interest in the Vida, see Weber, pp. 130-31.
} 
seventeen foundations were not as visible to her as they are, I think, on occasion, to the careful reader.

Several scholars who have written on Teresa's style in the Vida have argued that her rhetoric is deliberate, intended, among other things, to pre-empt the accusation by ecclesiastical superiors that she, a woman, is seeking to teach, in contravention of St Paul's interdiction (1 Cor. 14. 34-37; see also 1 Tim. 2. 11-14). One feature of her style that can be thought to mitigate the impression that, in setting out her supernatural experiences and her understanding of them, she is seeking to instruct her readers, is her diffidence. The voice the reader of the Spanish Vida hears often speaks hesitantly and imprecisely. It seems that for Matthew this was a product of misplaced humility. The English Teresa speaks with greater confidence. In part this impression results from a reluctance on the translator's part to render consistently into English the verb parecer (to seem) and the noun el parecer (opinion) used regularly by Teresa. One of Teresa's greatest afflictions was her fear that her visions might have been demonic (or the result of autosuggestion) rather than divinely inspired, a fear stoked at times even by those closest to her. Despite the devil's temptations aimed at convincing her that true visions could only be perceived by the eyes of the body, when she had experienced visions perceived by the imagination and intellect too, Teresa insists that she retained a belief that what she had seen in these latter manners did come from God, 'siempre me quedava un parecerme era Dios, y que no era antojo’ (p. 49; 7.7). Matthew's translation replaces this hesitant expression of instinctive belief with something a lot more forthright: the English Teresa announces that she was 'very confidently of opinion, that it was God, and no conceipt, or fauncie, at all' (p. 67). And when Teresa approaches the thorny matter of the relative qualities of the several categories of supernatural vision, presenting her understanding of this in a manner that some might consider to be didactic, she predictably waters down the conviction in her words with a parecer: '[e]s muy mucho de estimar esta vision, y sin peligro à mi parecer’ (p. 274; 28.10). Matthew’s Teresa 
has no such scruples and omits the caveat altogether, instructing '[t]his kind of vision, is to be valued, at a very high rate' (p. 397) tout court. ${ }^{29}$

Curiously, Sir Tobie seems reluctant, often, to translate the word casi (almost), as if he felt Teresa's statements ought to be more consistently categorical. Distinguishing contemplative union from ecstatic rapture she explains that whereas the latter is irresistible, in the former case 'resistir se puede casi siempre' (p. 175; 20.3). In Matthew's version 'it [resistance] may always, in effect, be employed' (p. 250). In chapter 20 Teresa confesses that she felt afraid almost whenever God first granted her a new form of supernatural favour, 'como me acaece casi en cada merced que me haze el Señor’ (p. 184; 20.16). The English Teresa experiences this fear of novel mercedes 'alwaies' (p. 263). Matthew appears to be dissatisfied even with the uncontroversial fact that most of Teresa's confessors were Jesuits. Whereas her Spanish specifies of them that 'casi siempre han sido destos benditos hombres de la Compañia de Jesus' (p. 226; 23.18), Sir Tobie, oddly, prefers to explain that they 'have, in effect, ever been, these blessed men of the Societie of JESUS' (p. 326). The common (though by no means consistent) omission of casi from Matthew's translation contributes to the effect of making his Teresa speak more categorically and confidently than the Spanish Teresa (whose printed words, let us not forget, had passed already through the (much coarser) filter of Fray Luis's editing before Sir Tobie saw them). The translation decisions I shall go on to discuss now compound this refashioning of Teresa's voice, making the English Teresa sound more ordered, learned and magisterial than the original.

One aspect of Matthew's intervention involves the tidying up of Teresa's prose, a process that was begun by Fray Luis, but is taken a lot further in The Flaming Hart. For example, both editors of Teresa's autobiography step in to present pairs of nouns (or nominal

\footnotetext{
${ }^{29}$ The translation choices I have been discussing are Matthew's. They do not find precedents in William Malone's 1611 translation. In this case Malone's Lyf translates all three occurrences of parecer set out above with a 'me thoght' or an 'in my opinion' (see pp. 39, 221 \& 260).
} 
phrases) in what they presumably consider to be an order more logical than Teresa's. Teresa explains that, according to spiritual experts with whom she has discussed the matter, she gained experience in prayer faster than others, more in the twenty-seven years that she had engaged in mental prayer 'que a otros en cuarenta y siete y en treinta y siete' ('than others in forty-seven and in thirty-seven’) (10.9). ${ }^{30}$ Fray Luis re-orders the numbers and Sir Tobie - translating as he was from a Spanish edition derived ultimately from Fray Luis’s 1588 princeps - follows the revised order. Sir Tobie undertakes this re-ordering more regularly, however, and in contexts where the ostensibly correct order does not seem quite as mandatory. In her preliminary comments relating to the famous allegory of the four waters, then, Teresa introduces the third stage, by which she compares the relatively modest active effort required by advanced practitioners of unitive prayer to the watering of a garden 'de un rio, ò arroyo' (p. 84; 10.9). The English Teresa inverts the order to place what the translator must perceive to be the lesser first: 'by meanes of letting in, some little Brooke or River’ (p. 117). Similarly, discussing the option of beginning prayer by meditating upon important episodes from the gospels, Teresa mentions that the narratives of 'la Passion y vida de Cristo' (p. 157; 13.13) should never be overlooked entirely, even by sensitive spirits that are wont to faint when calling to mind Jesus' suffering. Evidently feeling that it is imperative that the chronological climax of Christ's earthly life come as the second of this pair of nouns, Sir Tobie has his Teresa refer to 'the Life, and Passion of our Blessed Lord', characteristically adding in an epithet absent from the original. ${ }^{31}$ Further examples of this tendency could be given.

Blanca de los Ríos explains that the inaccuracy of Teresa's biblical quotations is due to her choice not to consult a copy of the Bible (or her inability to do so). ${ }^{32}$ Either Teresa believes

\footnotetext{
${ }^{30}$ This quotation is taken from the edition of the Libro de la vida prepared by Otger Steggink and revised with reference to Teresa's autograph manuscript (Madrid, 1986, p. 85), preserving the original order.

${ }^{31}$ Matthew appears to find it virtually impossible to resist adding in epithets. He fairly consistently translates Teresa's Dios, el Señor, and su Majestad with Almightie God, our Blessed Lord, and his Divine Majesty. This is one stylistic tic he has which makes his English prose seem rather prolix and grandiloquent, very unlike Teresa's. ${ }^{32}$ See Chicharro (editor), Libro de la vida, p. 64.
} 
the accuracy of her quotations is unimportant for her purposes or she wants her readers to think that she is unlearned, again with a view to erasing markers of intellectual authority from her discourse. Spanish readers of the earliest printed editions of the Vida find a partly sanitized version of the words Teresa herself wrote: her heavily Hispanicized Latin is corrected by Fray Luis for the 1588 princeps. ${ }^{33}$ Matthew’s ‘improvement’ of his source text again goes further.

The Spanish edition which - we have tentatively posited - Matthew may have used as a source text for this translation has Teresa quote the opening of Psalm 41(42) as she remarks how the burning love the soul feels for God during the ímpetus she is discussing reminds her of it: 'O quantas vezes me acuerdo, quando ansi estoy, de aquel verso de David: Quemadmodum desiderat cervus ad fontes aquarum' (p. 288; 29.11). Matthew's English Teresa completes the verse given in the Spanish and then translates the Latin into English, giving the reader the impression of punctiliousness and a desire to instruct: 'O how often doe I remember that Verse of David, whensoever I find my self in this case? Quemadmodum desiderat cervus ad fontes aquarum, ita desiderat anima mea ad te, Deus meus; As the Hart desires to plunge itself, into the springs of water: so doth my Soule desire thee, O my God' (p. 418). ${ }^{34}$ Matthew also translates Teresa's quotation from Psalm 101(102). 8, which comes to her mind as she considers spiritual solitude: 'But the words, whereof I speake were these: Vigilavi, et factus sum sicut passer solitarius in tecto. I have watched, and am become like a solitarie sparrow, upon the topp of a House' (p. 257). And again, Matthew completes the Latin verse and translates it when, recalling the exemplary death of Fray Pedro de Alcántara, Teresa remembers how he recited Psalm 121(122). 1: 'And when he saw, that he was even come to an end, he said the Psalme of: Laetetus sum in his, quae dicta sunt mihi: in domum Domini ibimus;

\footnotetext{
${ }^{33}$ For example, the famous opening of Psalm 41(42) goes, in Teresa's manuscript original, 'quemadmodum desiderad cervus a fontes aguarun'. Fray Luis imposes the Vulgate’s ‘Quemadmodum desiderat cervus ad fontes aquarum' in the first printed edition of the Vida and this correct reading remains in the 1630 Antwerp Spanish edition.

${ }^{34}$ The italics here are present in the original in this and the following two quotations from The Flaming Hart.
} 
I have rejoiced in that, which they have said to me: we will goe into the house of our Lord; and so, stooping downe, and kneeling he died' (p. 384). Translation of the Latin quotations into English is Matthew's standard practice. Teresa does not translate them into Spanish in her manuscript (and nor does Fray Luis in the princeps). Perhaps she felt it unnecessary for the religious readership she had primarily in mind; perhaps she was not able to do so reliably.

Matthew's correction of Teresa's manner of deploying verbal authorities extends beyond her Biblical quotations. When Teresa offers not a quotation but her own paraphrase of 1 Corinthians 10. 13, for instance, even then he corrects her words to make them correspond more closely to the Vulgate, which he was presumably following. God, Teresa believes, inspired her to think upon these words of St Paul, '[q]ue era Dios muy fiel, que nunca à los que le aman, consentia ser del demonio engañados’ (p. 224; 23.15). Unlike the Spanish Teresa, the English Teresa - characteristically - gets the paraphrase right: 'God is very faithfull, and ... he never suffers them, who love him, to be tempted above their strength', unquestionably a better translation of the Vulgate's 'tentari supra id quod posestis' than the Spanish Teresa's 'to be deceived by the devil'. (The shift to the third person shows some willingness at least on Matthew's part to bend a little to Teresa's lead.) More worryingly for an Anglophone reader wishing to come as close as possible to knowing Teresa of Ávila through her translated text, Matthew's translations of words spoken to her by God are even less exact, in spite of Teresa's declaring within the pages of the Vida that she took especial pains to ensure these words were given verbatim. ${ }^{35}$ There is a paradoxical mysteriousness proper to the mystical tradition in God's words to Teresa concerning the human soul, recorded in chapter 18: ‘[d]ixome el Señor estas palabras: Deshazese toda, hija, para ponerse mas en mi: ya no es ella la que vive, sino yo:

\footnotetext{
${ }^{35}$ At chapter 39.8 of the Vida Teresa writes that 'muchas cosas de las que aquí escribo no son de mi cabeza, sino que me las decía este mi maestro celestial; y porque en las cosas que yo señaladamente digo «esto entendí», o «me dijo el Señor», se me hace escrúpulo grande poner u quitar una sola sílaba que sea' (p. 462 of Chicharro (editor), Libro de la vida). 'Many things of which I write here came not from my head, but rather my heavenly teacher said them to me; and so, in places where I say expressly "this I understood" or "the Lord told me", I am very scrupulous about adding or removing so much as a single syllable.'
} 
como no puede comprehender, lo que entiende, es no entender entendiendo’ (p. 160; 18.13). ${ }^{36}$ Matthew's translation seeks rationally to explain the ineffable and as a consequence, I think, further (and unnecessarily) distorts the impression the English reader receives of Teresa's autobiographical voice. His translation has something of the pedant about it:

And our Lord said this to me, in these words: 'It [the soul] doth, my Daughter, dissolve, and defeat it self, to be so, the more ingulfed in me; for now it is no longer she, who lives, but I; and since she cannot comprehend that, which she understands, her very understanding it, after a kind of Morall way, which she doth, is really a not understanding it, after a strict, and comprehensive way, which she is not able to doe.' $(\text { p. 227) })^{37}$

The Flaming Hart seems to attempt a presentation of Teresa with her very human weaknesses and failings to some extent veiled over. Thus far we have considered translation choices whose effect has been to give the English Teresa more confident, more didactic, and less humble a voice than her Hispanophone model. Other translation choices have the effect of increasing the reader's impression of the importance to Teresa of a firm confessional identity and of orthodox precision in the discussion of potentially controversial doctrines.

Teresa's comments on heretics, on Lutherans leave the reader of the Vida in no doubt as to her allegiance to Catholic Christianity, yet in The Flaming Hart Matthew takes every opportunity to amplify this. 'Por un punto de aumento en la Fe, y de aver dado luz en algo à los hereges, perdería mil reinos’ (p. 193; 21.1), Teresa declares in chapter 21. The English Teresa specifies that her willing sacrifice of a thousand kingdoms would be intended for the benefit of 'the Holy Catholick Faith' specifically (p. 276). In chapter 25 Teresa insists that the

\footnotetext{
36 There is also an echo here of Galatians 2. 20.

${ }^{37}$ As is generally the case, William Malone's 1611 translation sticks much closer to the Spanish original, ending with the paradox faithfully conserved, with no attempt to unravel the mystery: 'it is not to understand understanding' (p. 128).
} 
devout soul will under no circumstances depart 'un punto de lo que tiene la Iglesia’ (p. 240; 25.12); in English that mandatory authority becomes ‘the Holie Catholique Church’ (p. 346). And, when restating the importance of absolute fidelity to the Scriptures Teresa explains that she thought that 'todos los fieles lo creian' (p. 438; 40.1); Matthew circumscribes the ranks of the faithful to 'Catholiques' (p. 638). Clearly, the adaptation of the original here speaks of the divisions within Western Christendom that had deepened and solidified between Teresa's redaction of the Vida in the mid-1560s and the preparation of Matthew's translation in the early 1640s. The translator's personal experience of religious controversy probably explains his decision to make the English Teresa more explicit in her orthodoxy (from a Catholic perspective) than she might be seen to be if her occasional woolliness in discussion of, for instance, the intercession of saints - the result, no doubt, of hasty composition - were read, instead, as evidence of superstition or heterodoxy. ${ }^{38}$

Teresa had a special devotion to St Joseph and in the early chapters of the Vida she expresses passionate enthusiasm for the efficacy of his intercession with God. In chapter 6.6, for example, she confesses ' $[\mathrm{n}] \mathrm{o}$ me acuerdo hasta aora averle suplicado cosa que la aya dexado de hazer' (40; 6.6). Aware, surely, that a hostile English reader might point to this as evidence of idolatry, Matthew is more careful than Teresa in his choice of words. His Teresa explains 'I cannot remember, that, hitherto I ever desired anie thing, by his meanes, which he hath failed to obtaine for me' (p. 54), clarifying that the saints cannot achieve miracles by their own power but only by begging that God exercise his if he wills it. Hacer (to do) is translated by to obtaine again in a similar context in chapter 6.8 (p. 55 of The Flaming Hart) and when Teresa describes

\footnotetext{
${ }^{38}$ Sir Tobie's conversion to Catholicism and his refusal to swear the Jacobean Oath of Allegiance resulted in his imprisonment in the Fleet, where he was regularly visited by the great and the good of the Anglican establishment who tested his doctrinal knowledge and resolve in a series of disputations intended to prompt him to recant. Interestingly, prior to his conversion, the doctrine of the intercession of saints was one with which he confessed he struggled, though once he became reconciled to it, he embraced it with the zeal of a convert. See in particular his True Historical Relation of the Conversion of Sir Tobie Matthew to the Holy Catholic Faith, edited by A. H. Mathew (London, 1904).
} 
commending herself to the prayers of the Virgin Mary in chapter 19 in the hope that this might lessen God's anger with her - 'para que os aplaque' (p. 166; 19.5), the English Teresa explains the prayers were addressed 'to the Queen of Heaven, that she may helpe to appease thee' (p. 236). The intervention is even clearer in chapter 27. 'Tomava santos devotos, porque me librassen del demonio’ (p. 254; 27.1), Teresa tells the reader; but in the words of Matthew’s protagonist this is expressed differently: 'I became devoted to some Saints; to the end, that, by their means, I might be delivered from the Divel' (p. 366). The Spanish Teresa understands the doctrine well enough. She knows the saints cannot themselves save her. She is simply writing in haste. This is demonstrated by her self-correction towards the end of the passage just mentioned: 'digo que lo acabasse con su Magestad' (p. 254), that is, she clarifies, that a particular saint might endeavour to procure the favour from God. Matthew’s translation choices increase the impression of doctrinal precision, however.

Aside from the matter of the intercession of saints, Matthew's translation seems to betray a desire more generally to pre-empt the foreseeable criticisms of readers unsympathetic to some salient specificities of baroque Catholicism, for example its distinctive Marian content and its placing of spiritual value in physical suffering. (Alternatively, he may wish to instill in his readers a fully contextualized, orthodox account of these doctrines.) Towards the end of chapter 39, in which she briefly describes a large number of mercedes received from God, Teresa notes how once, on the Feast of the Assumption, she was granted a vision of Mary's ascent into heaven during a trance. It had a great impact on her and as a result, she says:

[q]uedè con grandes effetos, y aprovechòme para dessear mas passar grandes trabajos, y quedòme grande desseo de servir à esta Señora, pues tanto mereciò. (p. 436; 39.26) 
Fascinatingly, Sir Tobie adds a phrase to his English version for which there is not the smallest prompt in the Spanish; clearly, he feels it necessary to ensure Teresa's devotion to Christ is explicitly recorded prior to her expression of devotion to the Virgin. He translates:

and I remained with great effects, and improvements, by it, towards a wish, of undergoing yet, greater afflictions, for the love of our Lord. And so it also gave me encrease of desires, to serve our B. Ladie, since both her dignitie, and merit, was so great. (p. 636)

As van Dijkhuizen has explained, in the early modern period, Catholic writers tended to hold that 'suffering pain, and experiencing it in all its physical intensity, is theologically and spiritually meaningful and efficacious, and is therefore even something to be actively sought'. This is because human suffering is a way of participating in Christ's Passion, of becoming one with him. They also considered it to have a soteriological potential, believing that earthly suffering might purge sins that would otherwise fall to be atoned for in purgatory. Conversely, for Calvin, 'the idea that physical suffering can have an effect on the fate of a Christian's soul is an intolerable impingement on Christ's unique role as Saviour, and on his unique bodily suffering' and '[s]uffering, bodily or mental, should not, therefore, be actively sought, but only accepted when it presents itself'. This attitude is one that led many Reformed Christians to reject the practice of mortification of the flesh, a practice that Protestant polemicists regularly seized upon, depicting it as distastefully gruesome and masochistic. ${ }^{39}$

Small adaptations of Teresa's Spanish cause the English Teresa to sound more in tune with the religious sensitivities of the post-Tridentine period than the Teresa of the Spanish Vida, who never felt the need to downplay the physicality of Hispanic Catholicism. Recalling

\footnotetext{
39 Jan Frans van Dijkhuizen, 'Partakers of Pain: Religious Meanings of Pain in Early Modern England', in van Dijkhuizen and Enenkel (editors), op. cit. pp. 189, 212 \& 215.
} 
the severe sicknesses that had afflicted her for most of her life, Teresa reports that 'destos males se me da ya tan poco, que muchas vezes me huelgo, pareciendome en algo sirve el Señor’ (p. 53; 7.11). Matthew's translation is, quite unusually, a little more hesitant than the original in this instance. His Teresa claims of her afflictions that 'sometimes I am even glad, I have them; as conceaving, that our Lord may be, peraduenture, served, in some sort, thereby' (p. 276). Similarly, the English Teresa's narration of the famous episode when she and her brother Rodrigo ran away from home, hoping to make it to North Africa where they would seek to win martyrs' crowns is more reserved in its physicality than the Spanish. The Spanish Teresa specifies the gruesome death she anticipated: ‘[c]oncertavamos yrnos à tierra de Moros, pidiendo por amor de Dios, para que alla nos descabeçassen’ (p. 4; 1.4). In Matthew’s translation Teresa remembers her younger self hoping, not to be beheaded, but just that 'we might come, by degrees, to loose our lives there, for our Lord' (p. 3), a euphemistic choice of words that robs the saint's autobiographical voice of some of its vivaciousness.

Finally, Sir Tobie’s lexical choices can have the effect of stripping out of Teresa's autobiographical voice some of its affective, affiliative charisma. This results in part from the inherent difficulty in translating some of her Spanish constructions into English and in part from the translator's rather ponderous, formal English style. Diminutives and superlatives are the most obvious example of difficulties inherent in translating Spanish. They can communicate a variety of tones, but in the Vida their frequent use lends Teresa's voice a charmingly conversational, intimate warmth. Teresa confesses that when she was a girl 'estava entonces enemiguissima de ser monja' (p. 12; 2.8). The effect of Matthew's translation is to make Teresa sound positively po-faced: 'though I were, at that time, in extremitie of being averse from becoming a Religious woeman’ (p. 15). Teresa's use of a diminutive in the context of a discussion of the very weighty and esoteric matter of the several degrees of beatitude available in heaven is characteristic of her Spanish narrative voice, of the lightness of her 
linguistic touch. She is determined, she says, to do all she can to win the highest prize, 'no querria por mi culpa perder un tantito de mas gozar' (p. 392; 37.2). The childlike wonder expressed by that tantito is transformed into solemn sobriety in The Flaming Hart; the English Teresa would lay down her life 'so, I might not loose the least imaginable proportion, of my enjoying anie Celestiall blessing’ (p. 571).

The directness and relative simplicity of some of Teresa's lexis is another feature that becomes distorted in The Flaming Hart. Teresa procured in her writings to avoid all forms of pedantry and affectation, urging her Discalced daughters to consider carefully the way they speak, ‘que vaya con simplicidad y llaneza y relisión, que lleve más estilo de ermitaños y gente retirada que no ir tomando vocablos de novedades y melindres' ${ }^{40}$ In the Vida, describing plainly a vision of a celestial throne Teresa remarks ‘[p]areciame sostenerle unos animales’ (p. 434; 39.22). The English Teresa seems unable to stand the bareness of that description and notes, instead, that the throne 'was upheld, by certaine Mysterious Beasts' (p. 633). And at times the Spanish Teresa's plain expression can drift into coarseness. For example, she mentions that her confessor advised her, when confronted with the devil, to cross herself and 'que ... diesse higas' (p. 283). The effect of mentioning this obscene hand gesture would have been most accurately communicated by substituting whatever the equivalent was in seventeenth-century England. Sir Tobie’s choice - he offers a euphemistic paraphrase - falls far short of achieving the impact of the saint's original vulgarity: his author-subject explains modestly that she was instructed 'to use some exteriour action, or signe of scorne' (p. 411). Perhaps most concerningly, however, Matthew's lexical choices have the potential to distort radically the depiction of Teresa's relationship with God, whom on multiple occasions she addresses by the relatively informal second-person pronoun vos: 'suplicava os à vos,

\footnotetext{
${ }^{40}$ Visita de Descalzas, section 42, in Obras completas, edited by Efrén de la Madre de Dios and Otger Steggink (Madrid, 2006), p. 852. Teresa instructs the nuns to speak 'simply, plainly and piously, preferring the style of the hermit or recluse over the picking up of linguistic novelties and affectations'.
} 
mirassedes la razon, que tenian’ (p. 168; 19.8). Here Teresa calls upon God, urging him to give ear to her enemies’ criticisms of her. Kieran Kavanaugh notes that Teresa's form of prayer 'was centered in friendship with Jesus and she developed her teaching out of her own mystical experience of the evolution of this friendship' ${ }^{41}$ This informal address is a vital element in the delineation of this friendship in the Vida. The Flaming Hart's protagonist distances herself from her God: she 'besought [her] Divine Majestie, to consider what little reason they had' (and note how - perhaps deliberately, perhaps unwittingly - Sir Tobie inverts the gist of Teresa's plea: in his English, Teresa does not call on God to listen to her enemies, as in the Spanish, but rather to dismiss their criticisms of her).

\section{[1 line \#]}

The inclusion in The Flaming Hart of multiple marginal notes compounds the effects detailed in our analysis of Matthew’s translation, turning Teresa's intimate, self-deprecatory confession into something approaching a hagiography. Fortunately, it is clear in the context of these notes that the voice is not intended as Teresa's own. It clearly belongs to her admiring translator. Generally, the notes: praise Teresa's words (sometimes expressing sheer wonderment); exhort the reader to take heed, drawing attention to particular passages Matthew considers especially important; make Teresa's typically guarded criticisms of others more overt; and attempt to explain religious practices or idiosyncratically Spanish objects with which he anticipates his Anglophone reader will be unfamiliar (for example, the arcaduces (buckets of a water wheel) of the second water). A small number of examples will suffice to demonstrate the notes' impact on the reader's impression of Teresa's character.

\footnotetext{
41 'Blessed Anne of St. Bartholomew', in The Heirs of St. Teresa of Avila, edited by Christopher Wilson (Washington, DC, 2006), pp. 59-71 (p. 60).
} 
For many scholars of the Vida Teresa's voice is essentially feminine and the selfdeprecation and diffidence that, we have seen, Matthew tones down have been considered facets of that gendered self-presentation. Teresa's feminine charm is evidently not something the translator chooses to highlight. On the contrary, alongside a passage in chapter 11.13, in which Teresa recommends a kind of stoical apatheia faced with either the presence or absence of supernatural gustos y ternuras, Matthew notes approvingly her suggestion that the pious soul should persevere in serving God 'with Justice, and Fortitude, and Humilitie’ (p. 131). Far from observing in the text the author's 'woman's heart', Matthew urges the reader in his marginal note to '[m]arke well these masculine, and massye words'. ${ }^{42}$ He expressly defeminizes his subject, then, in a move that can be seen to reinforce some of the changes he wrought to the main text. As we have seen, just as the translation mitigates certain linguistic and rhetorical features of Teresa's style that have been be considered typically feminine, it amplifies her piety and softens her self-condemnation. Lest the reader believe that Teresa might at any stage have risked damnation, in chapter 32, when she recounts her vision of the place prepared for her in hell, Matthew notes in the margin that '[t]his is not to be literally understood' (p. 471), proceeding to explain how God prevented Teresa from committing any mortal sin. Finally, by way of example, alongside the passage referred to above, in which Teresa expresses hope that her suffering might be a way of serving God, Matthew's marginal note celebrates his subject's attitude, reinforcing the effects of the translation choices that explicitly confessionalize the text. Some of Teresa's words can be read as a criticism of Reformed doctrines of salvation that play down the value of suffering and Matthew is quick to highlight this interpretation. Beside these words he writes '[t]his Saint you see, was certainly no Protestant' (p. 377). The words of this final example hint at important circumstances that might have conditioned Matthew's

\footnotetext{
${ }^{42}$ It is Dominique Deneuville who refers to Teresa's 'woman’s heart', in Santa Teresa de Jesús y la mujer, quoted in Weber, p. 8.
} 
fashioning of the English Teresa of 1642, a woman manlier, more resolute, readier to engage in polemic, and more certain of her own righteousness than the Spanish Teresa of the mid1560s.

\section{[1 line \#]}

Lefevere has argued that '[t]wo factors basically determine the image of a work of literature as projected by a translation. These two factors are, in order of importance, the translator's ideology ... and the poetics dominant in the receiving literature at the time the translation is made'. ${ }^{43}$ The first factor is indeed important. The latter - whilst it may help cast light on some aspects of Matthew's prose style - is less important in understanding his modus operandi than the disparate historical circumstances from which the Vida and The Flaming Hart emerged. These, it seems to me, are decisive in explaining the reasons for Matthew's decision to adapt his presentation of the autobiographical subject.

Teresa composed the Vida (and the several written confessions that preceded it) with a number of aims. She wrote under obedience to her confessors, who wished to understand their penitent's extraordinary experiences of prayer and the circumstances of her life to date that might be relevant to their determining whether to grant or withhold their approval. Teresa also seems, at certain points in the narrative, to envisage her words being read by other nuns of the Carmelite Order. Writing as she was at a time and in a place where her actions (and, to an extent, her identity) were potentially suspicious - she was a woman, a conversa, and an advocate of interior piety who seemed to wish to guide others down the path of unitive prayer - Teresa had to be cautious in her self-presentation. Those out of sympathy with her ambitions

\footnotetext{
${ }^{43}$ André Lefevere, Translation, Rewriting, and the Manipulation of Literary Fame (Abingdon: Routledge, 2016), p. 31.
} 
would, at best, have thought her a foolish, impressionable upstart, and, at worst, a damnable heretic. This need for caution, then, the need to pre-empt potentially dangerous criticisms of her behaviour, has for many provided an explanation for certain facets of her authorial voice in the Vida, including the self-deprecation, the hesitancy, the deference, the imprecision and also the beguiling charm that we have discussed. A woman who might so easily have fallen foul of the Inquisition, Teresa wrote a self-defensive apologia.

The circumstances in which Tobie Matthew translated Teresa's text were quite different. Twenty years before publication of The Flaming Hart Teresa had been declared a saint of the Counter-Reformation Church. Sir Tobie was commissioned to english the Vida by Teresa's Discalced successors, who considered her the fountainhead of their spiritual and political authority and the model each nun aspired to emulate. And Tobie Matthew and the Antwerp English nuns were exiles; they belonged to an oppressed religious minority that, upon the outbreak of the English Civil War in the year the translation was published, must have feared that their situation would deteriorate even further. That Matthew hoped for a royalist victory cannot be doubted. He dedicates The Flaming Hart to Queen Henrietta Maria, a known friend to the beleaguered English Catholics and also to the Carmelite Order. ${ }^{44}$ Using an unmistakably militaristic idiom, he invites the queen 'to march at the very head of that whole Troope' (f. * $3^{r}$ ) of Teresa's followers. In translating the Vida, then, it seems that Matthew wished his Teresa to shirk off some of the modesty and deference that characterized the original. He wanted the English Teresa to provide hope and inspiration to his readers, including the Antwerp nuns 'who are no lesse, then a kind of counterpoise, to the miserie of the times, wherein wee live' (f. $\left.{ }^{*} 6^{v}\right)$. To do this he evidently felt his Teresa needed to speak with a voice

\footnotetext{
${ }^{44}$ That Henrietta Maria was a defender of the Catholics of Great Britain is well known. Her Carmelite connections are less well known. As a child she had received religious instruction from the Carmelite nuns of the Faubourg St-Jacques. When she was forced to flee England during the Civil War she spent some time at that convent and she returned there when she heard of the king's execution in January 1649 (see Alison Plowden, Henrietta Maria: Charles I's Indomitable Queen (Stroud, 2001), esp. pp. 22 \& 218). Tobie Matthew, an accomplished linguist, acted as the queen's interpreter during her first encounter with England.
} 
more 'masculine and massye', more unmistakably Catholic and less equivocal in matters that an inattentive reader might misconstrue. The English Teresa did not need to be diplomatic and defensive. The beleaguered English Catholics, above all the exiles, needed her to be bold and belligerent. She was to be their celestial standard bearer.

Whilst Matthew's translation has served the scholarly purposes to which it has been put well enough, a reader anticipating an intimate encounter with Teresa of Ávila in the pages of The Flaming Hart should bear in mind that the authorial voice with which he will become closely acquainted is not actually Teresa's, or rather, it is not only Teresa's. It is inevitable that, when translated, Teresa's words are rewritten, but Teresa's voice, when englished by Matthew, emerges subtly but decisively distorted: he chooses to adapt several linguistic and rhetorical idiosyncrasies of Teresa's prose - important contributors to the characterization of her autobiographical voice. Teresa's voice is defeminized, confessionalized and formalized to such a degree that the impression that the implied character of Teresa makes is significantly different from that made by the voice of the original Spanish Vida. Matthew also adds many marginal notes that compound the distortion. The process of translating and editing Teresa's (in many ways) humble spiritual apologia produces, then, something of a literary chimaera belonging to the impossible genre of autohagiography.

As Weber has noted, Teresa’s first readers were quick to identify the idiosyncrasies of her style and to question her motives. Fray Alonso de la Fuente, a hostile contemporary and one that Weber describes as a 'very good reader of Teresa, alert to her ambiguities and strategies', saw vanity behind the humility topoi, 'he grasped the defensive function of her hyperbolic self-depreciation’. And Francisco de Pisa, a more sympathetic reader, still observed that Teresa, despite regular claims to the contrary, did not always heed the opinions of the learned men she consulted, preferring to follow her own counsel. ${ }^{45}$ The evidence of The

\footnotetext{
${ }^{45}$ Weber, pp. $158-65$ (p. 161).
} 
Flaming Hart suggests that Tobie Matthew was another early modern reader of the Vida who was very much alive to many of the tensions present within that text, particularly the tension Weber sees as resulting from Teresa's 'double bind', the simultaneous inclusion of explicit confessions of the author-subject's weakness, incompetence and sinfulness on the one hand, and, on the other, the more implicit, though equally necessary demonstration of her strength, her extraordinary abilities, and her saintliness. Whilst modern Teresian scholarship has embraced these tensions, the specific circumstances Tobie Matthew and the exiled Catholics faced in 1642 seem to have inclined the translator to mitigate them in his translation and more generally to have adapted Teresa's autobiography to the tacit purposes I suspect he hoped his englished Life might serve.

Sir Tobie Matthew’s translation had much to recommend it to the seventeenth-century reader interested principally in the events of Teresa's life to the mid-1560s and in her teaching on prayer and other forms of supernatural encounter. A seventeenth-century reader picking up The Flaming Hart expecting to experience an encounter with Teresa Sánchez de Cepeda y Ahumada would, however, have been faced with something different. Though, of course, unless he could also read the Spanish Vida he would not have been aware of the distance separating these two Teresas. Lefevere observed that 'rewriters', including translators, were responsible for creating 'images of a writer, a work'. ${ }^{46}$ On the basis of Matthew's translation an unknown number of Anglophone readers would have reconstructed in their several minds' eyes an image of Teresa different in a number of important respects from the one to emerge from the pages of the Spanish Vida, with consequences for the saint's reception in the Englishspeaking world that are yet to be identified and assessed.

Studies of early modern translations of Spanish Golden Age texts have usefully cast light upon the original works they treat. Most famously, Peter Russell's examination of early

\footnotetext{
${ }^{46}$ Lefevere, p. 4.
} 
modern translations of Don Quixote - in which he found that the novel's humour received most emphasis - permitted him to assert that for the pre-Romantic reader the novel was first and foremost 'a funny book' ${ }^{47}$ The evidence of the single translation considered in this essay is too modest to justify any general conclusion regarding the reception of Teresa's Vida in seventeenth-century Europe. Analysis of The Flaming Hart suffices, though, tentatively to suggest what it is that makes Teresa's spiritual autobiography a great book. It is something cast into relief when the translation is compared to the original Vida. It is, quite simply, the vivid presence behind its words of the extraordinarily captivating character of the author-subject, an inimitable, ebullient presence that will be sadly missed by any reader of The Flaming Hart familiar with Matthew’s Spanish source text.

47 ““Don Quixote” as a Funny Book’, in The Modern Language Review, 64 (1969), pp. 312-26. 